\title{
White Mensural Manual Encoding: from Humdrum to MEI*
}

\author{
Codificación manual mensural: de Humdrum a MEI
}

\begin{abstract}
David Rizo Valero
Escola d'Art i Superior de Disseny d'Alacant Instituto Superior de Enseñanzas Artísticas de la Comunidad Valenciana (ISEA.CV)

Universidad de Alicante david.rizo@easda.es

ORCID iD: https://orcid.org/0000-0003-3448-2688
\end{abstract}

Nieves Pascual León

Conservatorio Superior de Música de Valencia Instituto Superior de Enseñanzas Artísticas de la Comunidad Valenciana (ISEA.CV) nieves.pascual@csmvalencia.es ORCID iD: https://orcid.org/0000-0003-1917-6957

\section{Craig Stuart Sapp}

Center for Computer Assisted Research in the Humanities, Stanford University craig@ccrma.stanford.edu

ORCID iD: https://orcid.org/0000-0001-8865-3177

\footnotetext{
* This work was supported by the Spanish Ministerio de Economía y Competitividad through Project HISPAMUS Ref. No. TIN2017-86576-R (supported by UE FEDER funds), and partially by the ISEA.CV 2017/2018 research grants.
} 


\title{
David Rizo Valero, Nieves Pascual león y Craig Stuart SapP
}

\begin{abstract}
The recovery of musical heritage currently necessarily involves its digitalization, not only by scanning images, but also by the encoding in computer-readable formats of the musical content described in the original manuscripts. In general, this encoding can be done using automated tools based with what is named Optical Music Recognition (OMR), or manually writing directly the corresponding computer code. The OMR technology is not mature enough yet to extract the musical content of sheet music images with enough quality, and even less from handwritten sources, so in many cases it is more efficient to encode the works manually. However, being currently MEI (Music Encoding Initiative) the most appropriate format to store the encoding, it is a totally tedious code to be manually written. Therefore, we propose a new format named ${ }^{* *}$ mens allowing a quick manual encoding, from which both the MEI format itself and other common representations such as Lilypond or the transcription in MusicXML can be generated. By using this approach, the antiphony Salve Regina for eight-voice choir written by Jerónimo de la Torre (16071673) has been successfully encoded and transcribed.
\end{abstract}

Key words: Music Digital Encoding, Music, Hispanic White Mensural Notation, Baroque, Paleography, Music format, Digital humanities.

\section{RESUMEN}

La recuperación del patrimonio musical en el momento actual pasa necesariamente por su digitalización, no sólo mediante la obtención de imágenes digitales, sino también por la codificación en formatos legibles por un ordenador del contenido musical descrito en los manuscritos originales. En general, esa codificación se puede realizar mediante herramientas automatizadas basadas en lo que se denomina Reconocimiento Óptico de Música (OMR por sus iniciales en inglés), o manualmente escribiendo directamente el código informático pertinente. La tecnología OMR todavía no está lo suficientemente madura como para extraer con buena calidad el contenido musical de imágenes de partituras, y aún menos de fuentes manuscritas, por lo que en muchos casos es más eficiente codificar las obras manualmente. Sin embargo, es totalmente tediosa la escritura en el formato más adecuado para realizar esa codificación actualmente, MEI (Music Encoding Initiative). Por ello proponemos un nuevo formato denominado ${ }^{* *}$ mens que permite escribir manualmente el código de manera rápida y sencilla, a partir del cual, además, somos capaces de generar tanto el propio formato MEI como otras representaciones habituales como son Lilypond o la transcripción en MusicXML. Usando este enfoque, se ha codificado y transcrito la antífona a ocho voces Salve Regina escrita por Jerónimo de la Torre (1607-1673).

Palabras clave: Codificación digital de la música, Música, Notación Mensural Blanca Hispánica, Barroco, Fuentes Tipográficas, Paleografía, Formato musical, Humanidades digitales.

Rizo Valero, D.; Pascual León, N. y Stuart Sapp, C. (2018). White Mensural Manual Encoding: from Humdrum to MEI. Cuadernos de Investigación Musical, 6 (extraordinario), 373-393.

doi: 10.18239/invesmusic.v0i0.1953 


\section{White MENSURAL MANUAL ENCODING: FROM HUMdRUM TO MEI}

\section{INTRODUCTION}

The recovery of early music has gained interest in the last years. Many efforts are being done to restore old sources. In most cases a traditional approach has been followed: musicologists analyze and transcribe works into Common Western Modern Notation (CWMN) and accompany them with a discussion of the rationale of the decisions taken into the so-called critical edition.

Some new projects (Kirkman, 2015) are emerging that have their objective on making these transcriptions accessible through online services that, besides allowing for a much wider audience than printed editions, take advantage of computer based utilities such as the content based search. However, very few aisled projects (Rigaux et al., 2012) pay attention on the online reproduction of the original notation found in the manuscripts, and, for the best of our knowledge, there is no one reproducing fully diplomatic transcription scores. Thus, the need of having tools and computer formats available for digitally encoding early music has been limited to a restricted number of projects.

Some digital editions have been presented that explicitly encode early notation content in ad-hoc designed formats. One of the firsts attempts was proposed by Manion and Stinson in 1984 with the Scribe project (Stinson and Stoessel, 2014), where a software application and an encoding formats where developed (see Fig. 1 ).
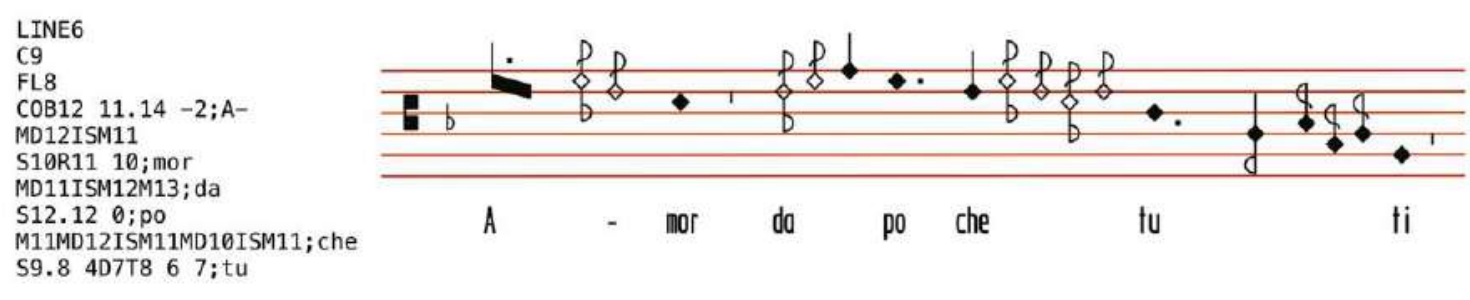

Fig. 1: Scribe encoding and rendering.

Maybe, the most serios attempt to create open tools for encoding mensural music so far has been the Computerized Mensural Music Editing (CMME) (Dumitrescu and Berchum, 2009). An eXtensible Markup Language (XML) based format (Selfridge-Field, 1997) was devised and both tools ${ }^{1}$ for inputting music and visualizing it with a number of specific features such as choosing between early and modern clefs were released. However, besides the "The Other Josquin"” Jase Rodin's project this work is not longer maintained.

Since then, the sounder proposal to encode early music in an open community driven format is the Music Encoding Initiative (MEI) (Roland, 2002, Roland et al., 2014). This XML based format allows the encoding not only common western modern notation music, but also analysis, traditional facsimile, critical, and performance editions, and what's more

\footnotetext{
${ }^{1}$ https://github.com/tdumitrescu/cmme-editor
}

2 http://www.cmme.org/database/projects/14 


\section{David Rizo Valero, Nieves Pascual león y Craig Stuart SapP}

interesting, neumatic and mensural notations, allowing. Besides, it can be adapted to user's needs though a customization process.

Once MEI and it's customization protocol had been made available, Scribe creators decided to make this project data more accesible by writing a customization of MEI named MEI NeoScribe. By using a command-line Unix tool, the original data in Scribe was ported to a MEI-like format (Stinson and Stoessel, 2014).

Created as "a tool for music editors in order to compare early music editions and reeditions when compiling comprehensive critical modern editions" , the Aruspix project was the first available tool able to recognize printed mensural manuscripts and to convert them into a computer readable symbolic format (Pugin, 2009) using OMR. The music editing tools were conceived to correct the output of OMR and to superimpose and collate early music prints (see Fig. 2).

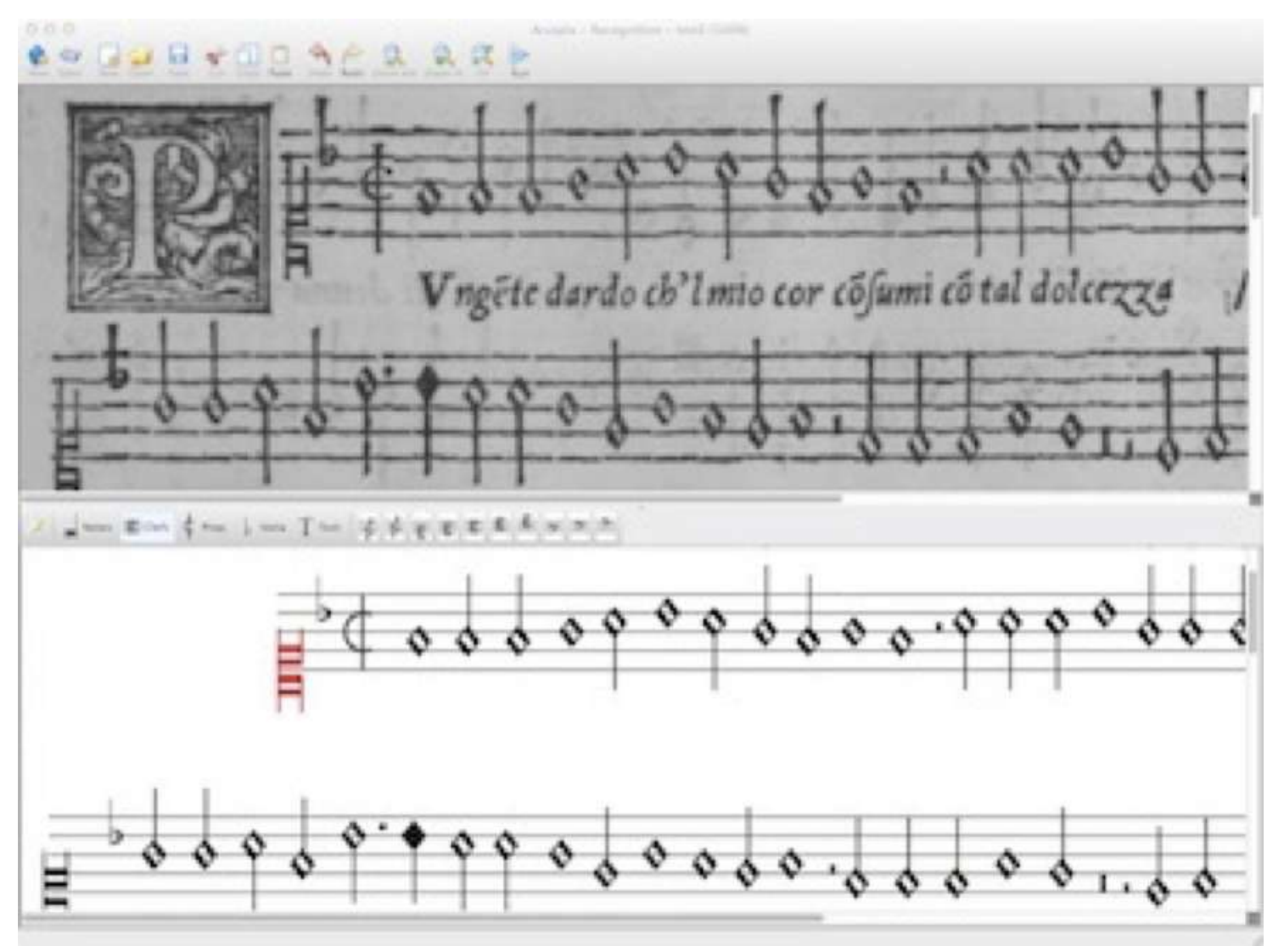

Fig. 2: Aruspix screenshot.

The absence of usable encoding tools was evinced by Elias and Desmond (Thomae Elias and Desmond, 2017), who introduced a method to encode mensural music using the Sibelius commercial notation editor. As this editor does not include tools to work with this

\footnotetext{
${ }^{3}$ http://www.aruspix.net
} 
kind of notation, they devised a workaround by using articulation marks not present in mensural notation that were used to denote specific mensural features. Then, after using the SibMEI Sibelius plugin ${ }^{4}$ to export MEI format, a script was developed to replace those marks with the expected mensural property (see Fig. 3).

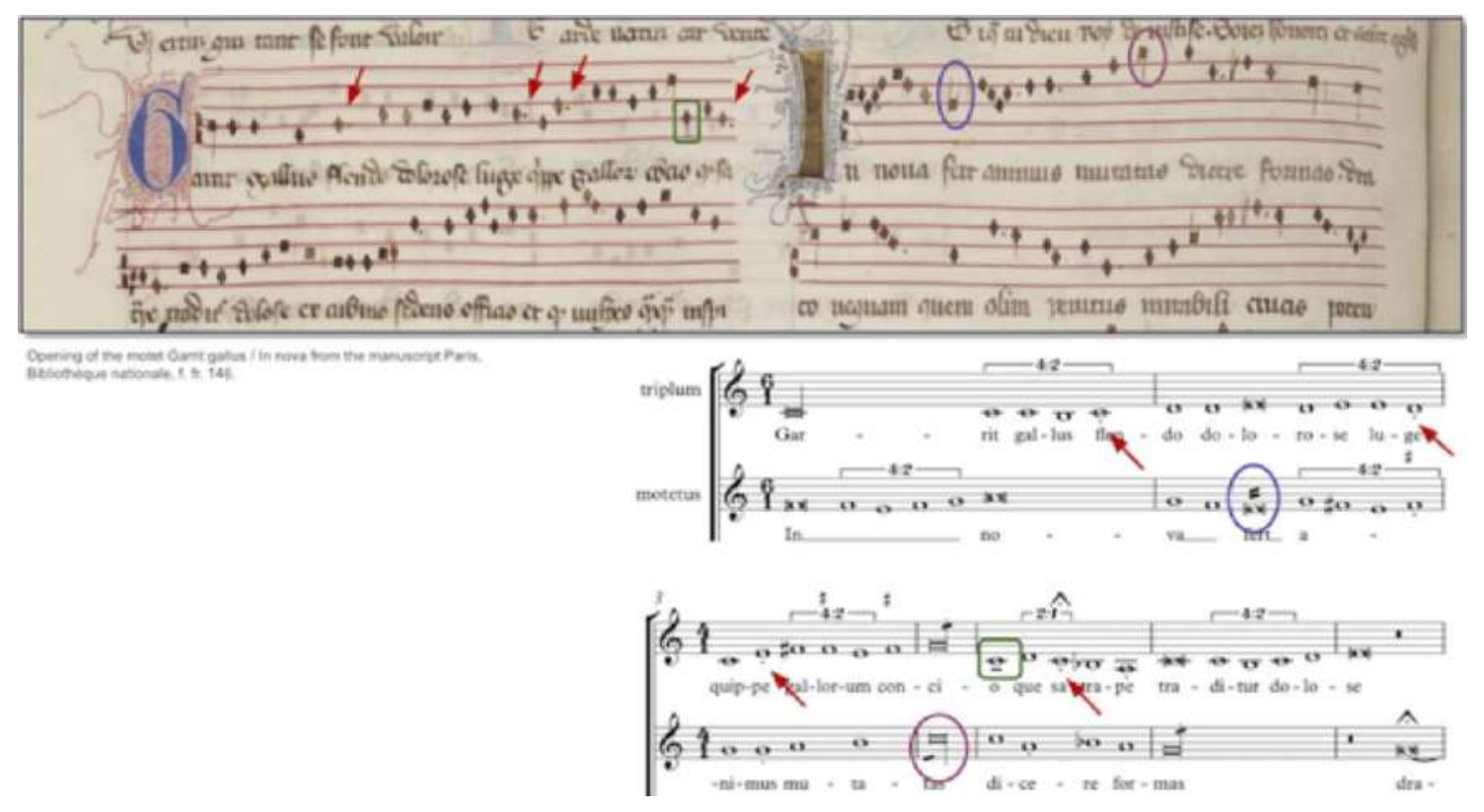

Fig. 3: Martha Thomae and Karen Desmond Sibelius workaround.

Another example showing this lack of a stablished workflow to encode early music can be found in the SEILS (Symbolically Encoded Il Lauro Secco) corpus (ParadaCabaleiro et al., 2017). This dataset contains Italian Madrigals from the 16th Century, but unfortunatelly not encoded in original notation but in modern transcription in MIDI (MIDI, 1996), MusicXML (Good and Actor, 2003) and Lilypond ${ }^{5}$ formats.

Other project in which the modern transcription is offered instead of the original early notation is the Josquin Research Project (Kirkman, 2015), where different formats such as MusicXML, MEI, and MIDI are available along with PDF score renderings and some useful analysis tools. In this project, works are encoded using a Finale/MusicXML based procedure ${ }^{6}$.

Having the improving of OMR technology as objective, the Calco tool (Sober-Mira et al., 2017) was developed to create ground-truth data for training machine learning systems. This application, that allows to easily obtain sequences of musical symbols and their position in the staff from hand strokes on the manuscript image, however, does not encode the output in any standard format.

\footnotetext{
${ }^{4}$ https://github.com/music-encoding/sibmei377

${ }^{5}$ http:/ / lilypond.org

${ }^{6}$ http://wiki.ccarh.org/wiki/Josquin_Project_encoding_standards 


\section{David Rizo Valero, Nieves Pascual león y Craig Stuart SapP}

Given this scenario, if a new project for encoding and transcribing early music is planned, it is currently difficult to know which workflow of tools and encoding formats should be chosen. It seems that the most sensible decision is to choose MEI as encoding format. Regarding the tools to be chosen, although OMR based tools are the most promising ones, nowadays there is not any robust enough application able to deal with all kinds of manuscripts, either those very well maintained or damaged handwritten papers (see Fig. 3). Thus, in this context, currently the best option to encode MEI is to manually write directly XML format or use the above mentioned Elias and Desmond's Sibelius workaround (Thomae Elias and Desmond, 2017). In fact, the community is using XML editors such as Oxygen ${ }^{7}$ for the task.

However, due to the verbosity of the XML text to be written, this is a very tedious and error-prone method.

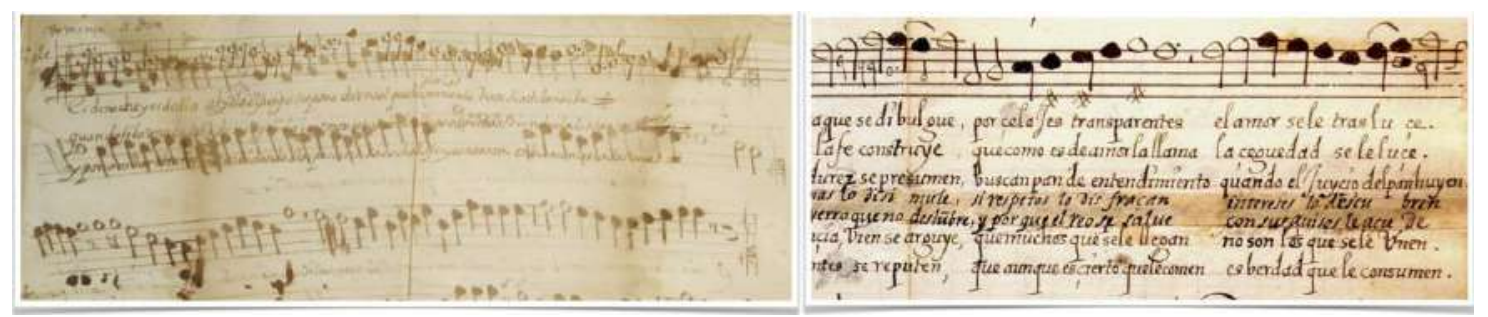

Fig. 4: OMR systems are currently unable to deal with this kind of manuscripts.

For filling this gap, in this work we propose a format to quickly encode by hand early notation music, specifically, white mensural polyphonic works, from which we are able to generate MEI encoding for their preservation. As our objective is not to substitute MEI, but to provide a tool for simplifying its writing, we defer any diplomatic nuance to its manual editing directly in the generated MEI file. Based on the previous experience of manually encoding CWMN works with Humdrum's **kern format (Huron, 2002), such as most of the Chopin works, we have designed a new Humdrum format named $* *$ mens for encoding white mensural notation. Repertory-specific issues similar to the ones referred to in (Zitellini and Pugin, 2016) are addressed using markup and tools to convert the data into MEI. The Verovio Humdrum Viewer (VHV) (see Fig. 5) (Sapp, 2017) has been extended to work with ${ }^{* *}$ mens. Thus, the user writes directly the content using **mens, and VHV can represent visually the content rendered and export to MEI. Additionally, the IM3 library $^{9}$ has been also extended to convert from/to **mens and MEI and other formats, such as Lilypond, and MusicXML or MIDI in their CWMN translation.

\footnotetext{
${ }^{7}$ https://www.oxygenxml.com

${ }^{8}$ https://verovio.humdrum.org

${ }^{9}$ https://github.com/davidrizo/im3
} 
The approach has been used as the encoding method in the context of the Patriarca project $^{10}$ to transcribe 17 th-Century late white mensural notation manuscripts at the Real Colegio Seminario del Corpus Christi in Valencia (E-VAcp-Mus) containing dozens of works of composers ranging from Diego Pontac (1603-1654) to Antonio Teodoro Ortells (1649-1706).

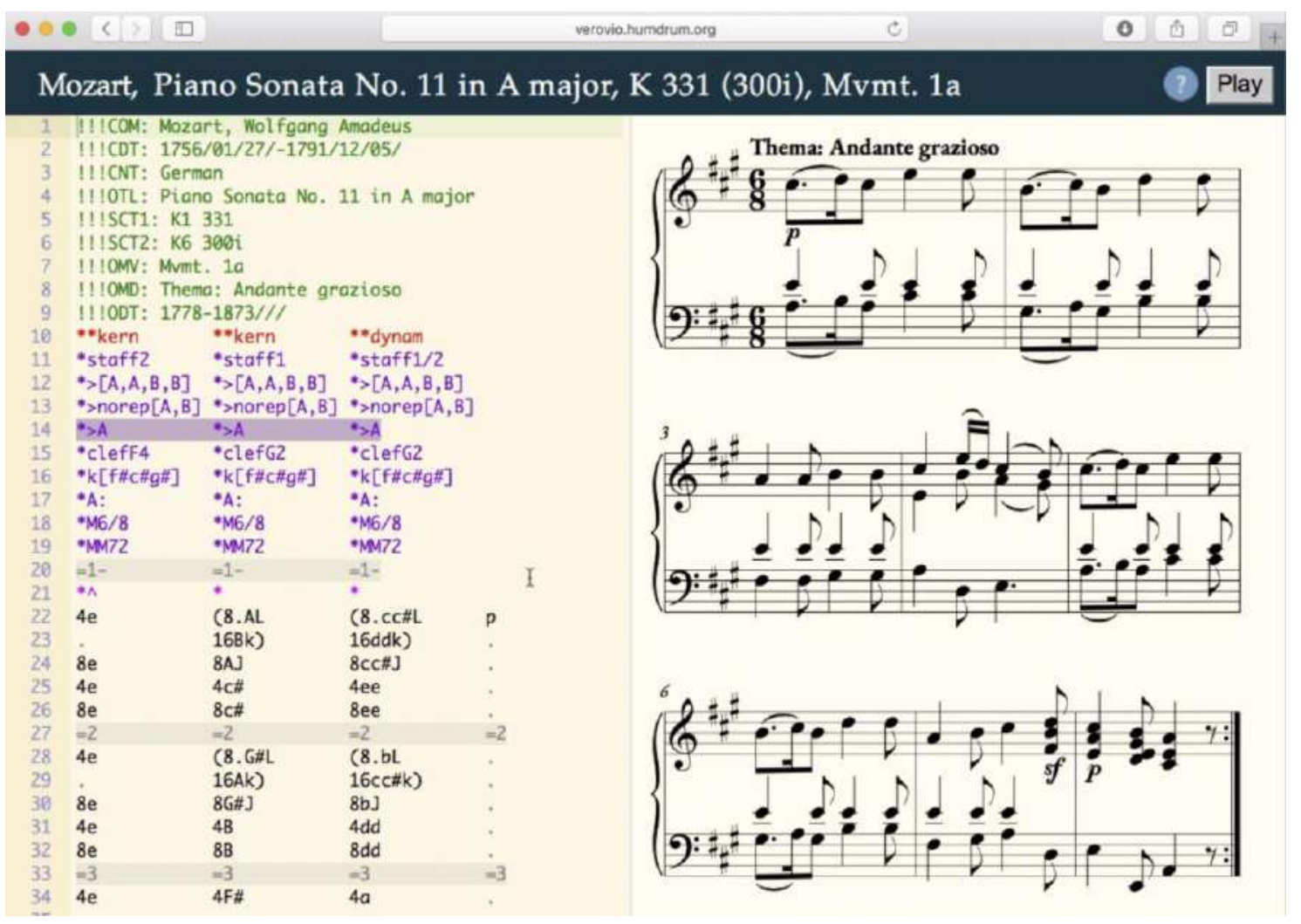

Fig. 5: Verovio Humdrum Viewer snapshot (1649-1706).

\section{2. ***MENS FORMAT}

The **mens format has been developed based on the main Humdrum's **kern philosophy. Music is encoded in text files that can be written using any text editor. Data is organized in columns, named spines, each one containing a voice: the leftmost column containing the bottom voice in the score (e.g. the bass in a choir sheet), the rightmost representing the top voice (e.g. the soprano in a typical SATB arrangement). Each item can represent either actual notes and rests, continuations of them, context modifiers such as key and time signatures or clefs, or some visual indicators such as bar lines. See an example in Figure 6.

${ }^{10}$ The Patriarca project is been developed during the academic year 2017/2018 by the authors and sponsored by the Instituto Superior de Enseñanzas Artísticas de la Comunidad Valenciana (ISEA.CV) 


\section{David Rizo Valero, Nieves Pascual León y Craig Stuart Sapp}

\begin{tabular}{|c|c|}
\hline$\star \star$ mens & $\star \star$ mens \\
\hline *I"Rests & *I"Notes \\
\hline${ }^{*} \mathrm{clefC} 3$ & *clefC 3 \\
\hline $\mathrm{Xr}$ & $\mathrm{Xc}$ \\
\hline Lr & Lc \\
\hline $\mathrm{Sr}$ & $\mathrm{Sc}$ \\
\hline sr & $\mathrm{sc}$ \\
\hline $\mathrm{Mr}$ & $\mathrm{MC}$ \\
\hline$m r$ & $\mathrm{mc}$ \\
\hline Ur & Uc \\
\hline ur & uc \\
\hline$=||$ & $=||$ \\
\hline * & $\star_{-}$ \\
\hline
\end{tabular}

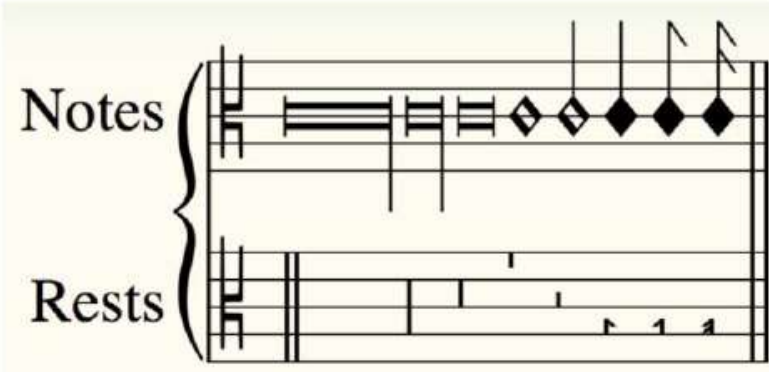

Fig. 6: Simple ${ }^{* *}$ mens encoding of notes and rests.

Most of the encodings necessary to encode mensural notation are already available in **kern, such as all metadata fields, key signature specification, or pitches. However, many other codes have been added that are not present in CWMN, such as the ones denoting perfection or mensuration. The complete grammar is detailed in IM3 source repository ${ }^{11}$.

Global comments, i.e., comments that take a full line, begin with the literal '!!!'. Metadata lines are a specific case of global comments where some specific three character codes follow that literal. Those metadata come from the main **kern syntax: 'COM' is used to denote "composer", 'ENC' for “encoder", 'END' for the date the encoding was finished, and 'OTL' for encoding the title. In any other case, each line contains a sequence of one or more columns divided by tabulators, representing each one a different voice. If the work is a typical choir soprano, alto, tenor and bass arrangement, the file will have four columns, ordered from left to right as bass, tenor, alto, soporano, i.e., simulating the score layout as if it were rotated counterclock- wise. Each column must start with the header **mens. Usually, reusing **kern syntax, the instrument name is denoted by a '*I' code followed by the literal containing that name. Clefs are specified the same way as in**kern by means of the '*clef' code followed by one of 'G2', 'C1' to 'C5', 'F3', and 'F4' denoting the clef note name and its line position. Key signature is also denoted following the ${ }^{* *}$ kern syntax, that is ' $\mathrm{k}[A C C S]$ ' where ' $A C C S$ ' is replaced by the sequence of altered pitches (e.g. '*k[f\#c\#]' represents $D$ Major, and '*k[b-e-]' denotes Bb Major). Time signature can be specified using a mensuration sign using the code 'met(MS)', where ' $M S$ ' stands for one of the mensuration signs listed in table found in Figure 7. If any bar line is found, it is encoded employing the $* *$ kern format, by using ' $=$ ' as minimal expression, that can be followed by a number of modifiers, such as the number of the bar.

\footnotetext{
${ }^{11}$ https://github.com/davidrizo/im3/blob/master/imcore/src/main/antlr4/es/ua/dlsi/im3/core/score/io/ kern/grammar_ebnf.txt
} 
WHite MENSURAL MANUAL ENCODING: FROM HUMdRUM TO MEI

\begin{tabular}{|c|c|c|c|c|c|c|c|c|c|}
\hline C & $\star \operatorname{met}(\mathrm{C})$ & $\Phi$ & $\star \operatorname{met}(\mathrm{C} \mid)$ & $\bigodot$ & $\star \operatorname{met}(\mathrm{C})$. & 0 & $\star \operatorname{met}(0)$ & $\odot$ & $\star \operatorname{met}(0)$. \\
\hline 2 & $\star \operatorname{met}(2)$ & 3 & $\star \operatorname{met}(3)$ & $\mathrm{C} 2$ & $\star \operatorname{met}(\mathrm{C} 2)$ & $\mathrm{C} 3$ & $\star \operatorname{met}(\mathrm{C} 3)$ & $\mathrm{O} 2$ & $\star \operatorname{met}(\mathrm{O} 2)$ \\
\hline$\$ 2$ & $\star \operatorname{met}(\mathrm{C} \mid 2)$ & $\Phi$ & $\star \operatorname{met}(\mathrm{C} . \mid)$ & $\Phi$ & $\star \operatorname{met}(01)$ & $\Phi 3$ & $\star \operatorname{met}(0 \mid 3)$ & $\mathrm{O} 3$ & $\star \operatorname{met}(03)$ \\
\hline$\$ 3$ & $\star \operatorname{met}(\mathrm{C} \mid 3)$ & § & $\star \operatorname{met}(0 / 3)$ & $\frac{3}{2}$ & $\star \operatorname{met}(3 / 2)$ & 0 & $\star \operatorname{met}(\mathrm{Cr})$ & $\frac{d}{3}$ & $\star \operatorname{met}(\mathrm{C} \mid / 3)$ \\
\hline$\frac{\$}{2}$ & $\star \operatorname{met}(\mathrm{C} \mid / 2)$ & $\Phi$ & $\star \operatorname{met}(\mathrm{C} \mid \mathrm{r})$ & $c_{3}$ & $\star \operatorname{met}(\mathrm{C} 3 / 2)$ & $\$_{3}$ & $\star \operatorname{met}(\mathrm{C} \mid 3 / 2)$ & & \\
\hline
\end{tabular}

Fig. 7: Mensuration signifiers.

The main content, that is made of notes and rests, use the **kern guidelines where some features have been added to represent specific white mensural notation. A rest is represented as the sequence 'DURr', where 'DUR' stands for a duration modifier from Table 1 (see example in Fig. 6). This way, a maxima rest is encoded using the code ' $\mathrm{Xr}$ '.

\begin{tabular}{|c|l|}
\hline Duration signifier & Mensural figure \\
\hline $\mathrm{X}$ & Maxima \\
\hline $\mathrm{L}$ & Longa \\
\hline $\mathrm{S}$ & Breve \\
\hline $\mathrm{S}$ & Semibreve \\
\hline $\mathrm{M}$ & Minima \\
\hline $\mathrm{m}$ & Seminima \\
\hline $\mathrm{U}$ & Fusa \\
\hline $\mathrm{u}$ & Semifusa \\
\hline
\end{tabular}

Table 1: Mensuration signs.

The notation of pitches follows exactly the format used in **kern, i.e., 'DURpitch' where 'pitch' is represented as a sequence of either uppercase (for notes under C3), or lowercase (for notes above C3) characters ' $a$ ' to ' $\mathrm{g}$ ', where the number of characters denote the octave. For encoding an optional accidental, the modifiers '-' for flat, '\#' for sharp, and ' $n$ ' for natural are used.

Figure 6 contains a very simple sample of this format. Once encoded in **mens, it can be is exported automatically either with VHV or IM3 to the MEI listing in Figure 8. 


\section{David Rizo Valero, Nieves Pascual León y Craig Stuart Sapp}

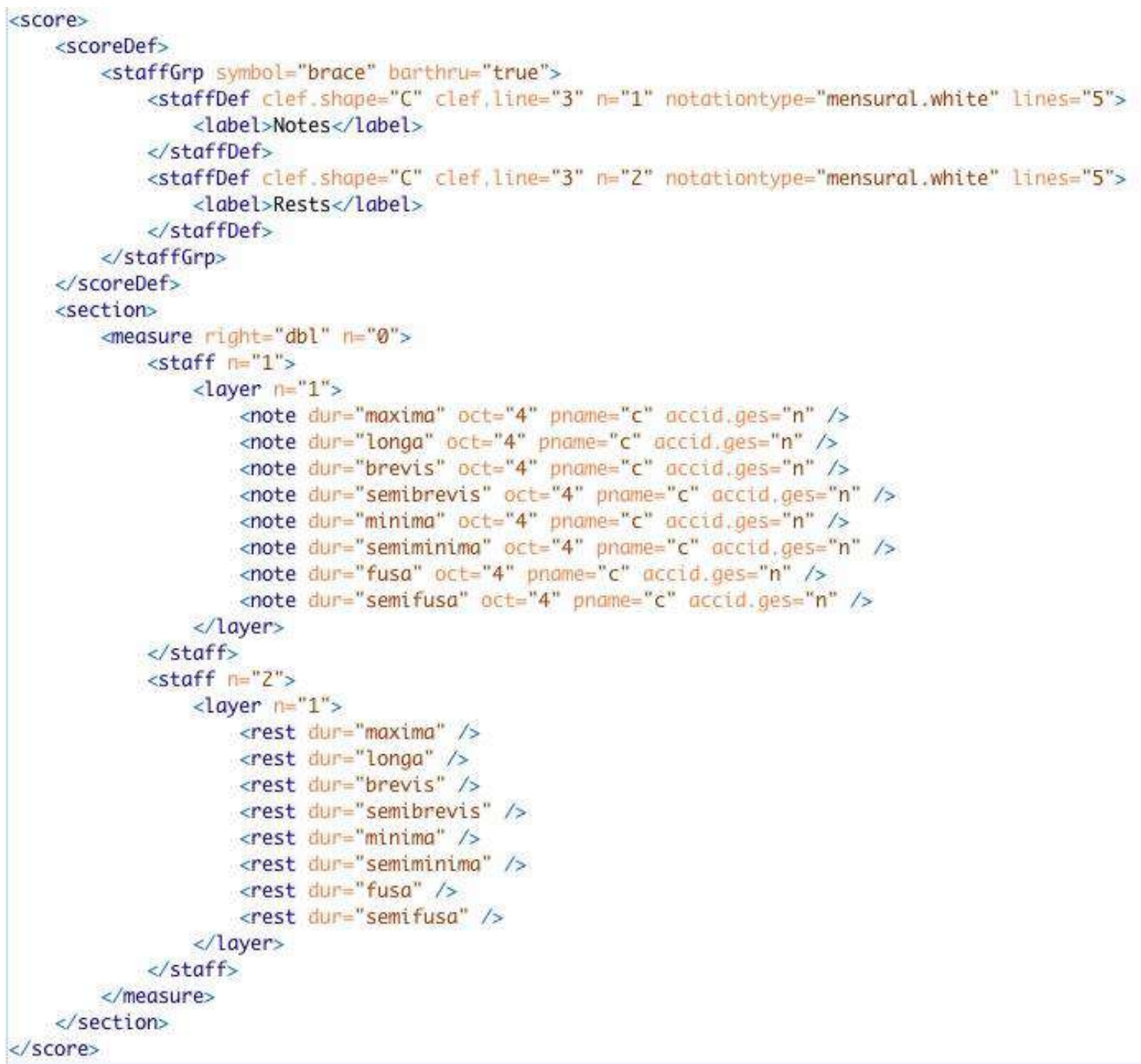

Fig. 8: MEI encoding of $* *$ mens code in Figure.

\subsection{PERFECTION ENCODING}

For some ternary mensuration signs, some figures can be interpreted having equivalent to the duration of two notes of lower order or three of them. This is named perfection: a note is perfect if it corresponds to three subdivisions, or imperfect when equate to two of them.

**mens allows for this distinction by including the codes ' $\mathrm{i}$ ' for imperfect and ' $\mathrm{p}$ ' denoting perfect. The use of this code can is shown in Figure 9. Breve notes are explicitly encoded as perfect or imperfect, semibreve is imperfect given the mensuration, so no code has to be written. 


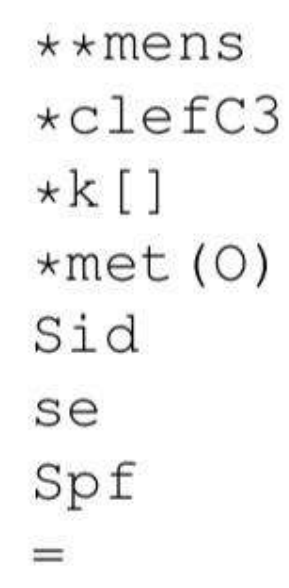

(a) Encoding

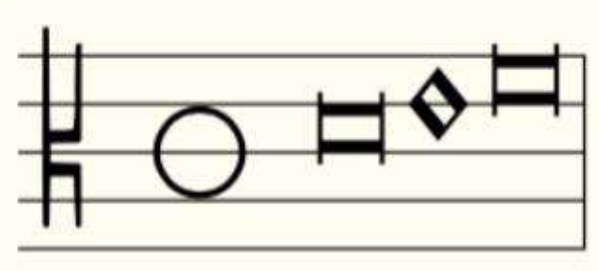

(b) Rendering

Fig. 9: Perfection.

\subsection{DOTS}

The dot symbol in white mensural notation can be given two different meanings depending on the context it is found. It can be a punctus additionis, with the same function as the one used in CWMN, that is, enlarge the duration of the preceding note with a half of its nominal duration, or a punctus divisionis used to disambiguate some specific sequences of figures. In **mens, the colon ' $:$ ' has been used as the code for denoting both kind of dots that can be appended to note (e.g. 'Sf:' denotes a breve F4 note).

In CWMN, punctus additionis evolved to what it is known as augmentation dot, that is represented in ${ }^{* *}$ kern as a dot after the duration signifier (e.g. '2.c' is a C4 dotted half note). This same principle could be used in mensural notation if the encoder knows exactly it has that function. However, our guidelines is to always use the colon to encode. This decision allows us to encode some weird situations in which a bar line is found between the note figure and the dot, maybe because it was added afterwards on the original manuscript. Following as principle that in Humdrum music encoding for being able to be automatically analised, this situation has been solved by explicitly dividing the duration broken by the bar line and encoding this eventuality with the signifiers ' $T$ ' and ' $t$ ', denoting tie start caused by a dot after a bar line and tie end (see Fig 10). 


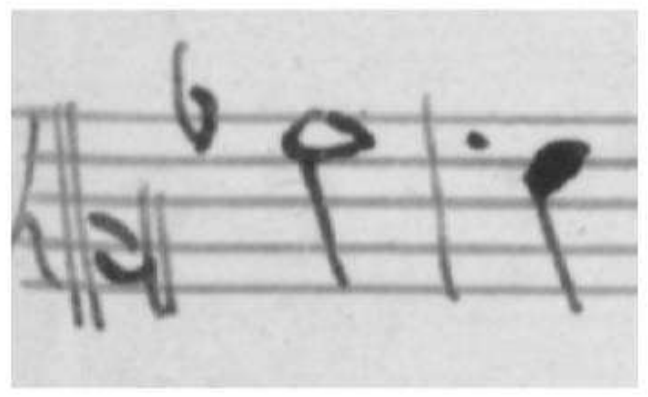

(a) Manuscript

$$
\begin{aligned}
& \star \star \text { mens } \\
& \star \mathrm{clefC} 2 \\
& \star \mathrm{k}[\mathrm{b}-\mathrm{b} \\
& \mathrm{MaT} \\
& =
\end{aligned}
$$

mat :

mg

\section{(b) Encoding}

Fig. 10: Punctus additionis encoding after a bar line.

\subsection{Alteratio}

The duration of figures in the context of some mensurations depends on the surrounding elements. Thus, a sequence of breve, semibreve, semibreve, and breve figures in an $\mathrm{O}$ meter (tempus perfectum, prolatio minor), must be interpreted with durations 6, 2, 4, 6 (see Fig. 11) (Querol Gavaldá, 1975:55) in what is known as alteratio.

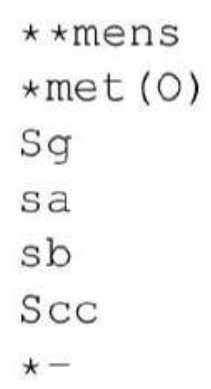

(a) Encoding

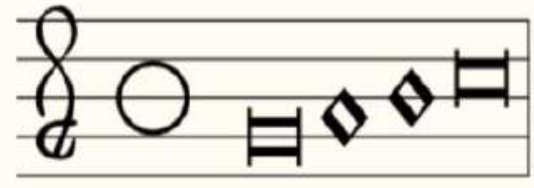

(b) Rendering

$$
\begin{aligned}
& \star \star \text { mens } \\
& \star \text { met }(0) \\
& \text { Spg } \\
& \text { sia } \\
& \text { sib } \\
& \text { Spcc } \\
& \star-
\end{aligned}
$$

(c) Performance encoding

Fig. 11: Alteratio.

As above introduced, the dot can be given the function of disambiguate situations by separating notes. This is the case of the punctus divisionis shown in Figure 12. 


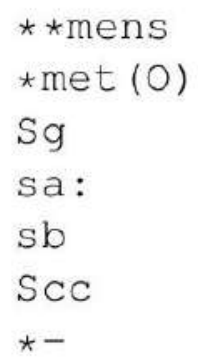

(a) Encoding

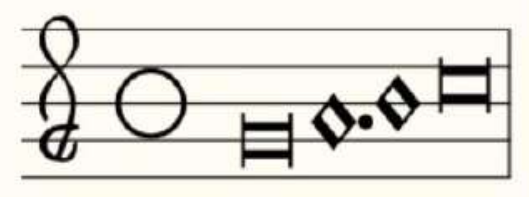

(b) Rendering $\star \star$ mens

$\star \operatorname{met}(0)$

Sig

sia:

sib

Sicc

$\star-$

(c) Performance encoding

Fig. 12: Punctus divisionis.

\section{4. COLORING}

Coloring of note heads is another specific feature of mensural notation. Depending on the period, note coloring adopts different meanings. In white mensural notation, only the differentiation between void note heads and black ones must is to be considered. Thus, a code has been introduced to be used optionally just next to the duration signifier (see Fig. 13) (Querol Gavaldá, 1975: 59).

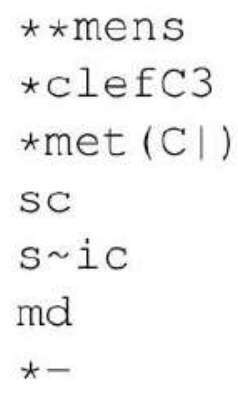

(a) Encoding

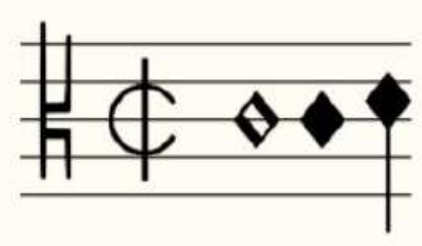

(b) Rendering

Fig. 13: Coloring.

All kinds of coloring use the same graphical mark. Figure 14 shows two similar examples using or not the coloring code (Querol Gavaldá, 1975: 57). 


\section{David Rizo Valero, Nieves Pascual León y Craig Stuart SapP}

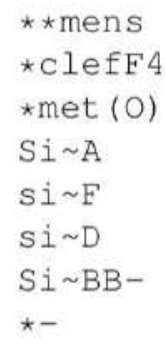

(a) Major coloring encoding

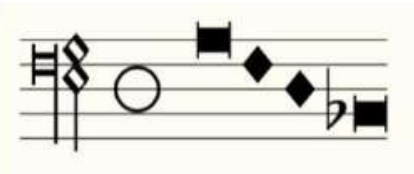

(b) Major coloring rendering

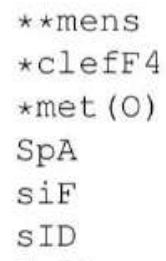

(c) No coloring encoding

Fig. 14: Major coloring.

\subsection{LIGATURE}

Ligatures are sequences of notes forming a melisma represented by a single figure body, each one with its own duration and pitch, even with a possible dot. Reusing all above explained note encoding, a ligature is specified in $* *$ mens just by surrounding the notes the ligature embeds with ' $<$ ' and ' $>$ ' delimiters.

There are ligatures whose visual representation depend on the duration of the involved notes (e.g. a ligature of longa descending notes, i.e., sine propietate et cum perfectione (see Fig. 15 (a) and (b)). However, there are other cases where the shape, either recta or obliqua must explicitly encoded. For allowing this distinction, the encoder may use the suffixes 'R' and 'Q' respectively for recta and obliqua connections (see Fig. 15 (c) and (d)).

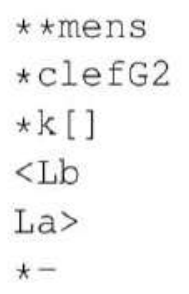
(a) Implicit implicit encoding shape encoding

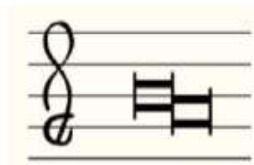

(b) Rendering of implicit encoding

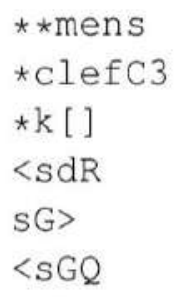

$\mathrm{SC}>$$$
\star-
$$

(c) Explicit shape encoding

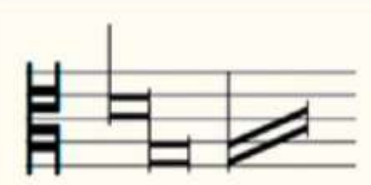

(d) Rendering of explicit encoding

Fig. 15: Ligature. 


\subsection{VISUAL SPECIFIC ASPECTS}

There some graphical symbols whose function differ from the one used in CWMN. This is the case of sharps, that if are attached to a note that was previously affected by a flat, leaving it as a non altered natural pitch (see Fig. 16). This example contains another interesting case: the last B pitch note should be interpreted as a B flat, however, this alteration is not explicitly written in the manuscript. This is solved by adding an editorial accidental ('xx' suffix). In both cases, the 'ILO' prefixed field is denoting a visual specific aspect, that could be removed without changing the actual interpreted music content. This way, 'LO:N:va=\#' is indicating that the note coming next should be visually altered with an accidental sharp.

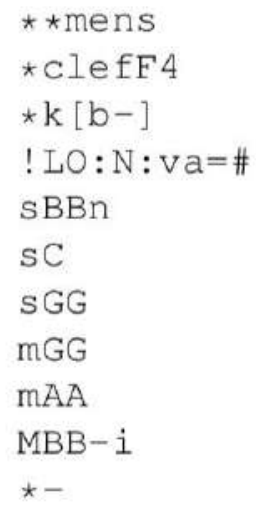

\section{(a) Encoding}

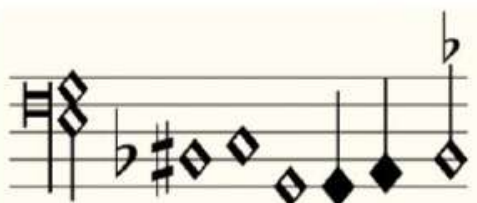

(b) Rendering

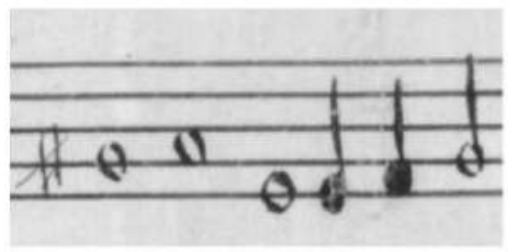

(c) Source manuscript

Fig. 16: Editorial accidental.

\section{JERÓNIMO DE LA TORRE TRANSCRIPTION}

The approach is being used as the encoding method in the context of the Patriarca project to transcribe 17th-Century late white mensural notation manuscripts at the Real Colegio Seminario del Corpus Christi in Valencia containing dozens of works of composers ranging from Diego Pontac (1603-1654) to Antonio Teodoro Ortells (16491706). In this paper, we present the encoding of the double choir eight-voice antiphony Salve Regina (see Fig. 17), under the symbol E-VAcp-Mus / CM-T-4 in the archive, written by Jerónimo de la Torre (1607-1673) (De Jaime Gómez and De Jaime Lorén, 1988), composer and organist active in the Cathedral of Valencia from its access in 1645 until his retirement in 1665. Although the document lacks exact dating, it is possible to date it around 1650. The notation signs are the usual ones in the Hispanic baroque repertoire. Some precautions have be taken, such as avoiding the confusion between the punctus additionis and the horizontal stroke corresponding to the minima rest. In this case study, the original work has not the added difficulty of interpreting perfection; nevertheless, as above exposed, the system is designed to tackle with it. 


\section{David Rizo Valero, Nieves Pascual León y Craig Stuart Sapp}

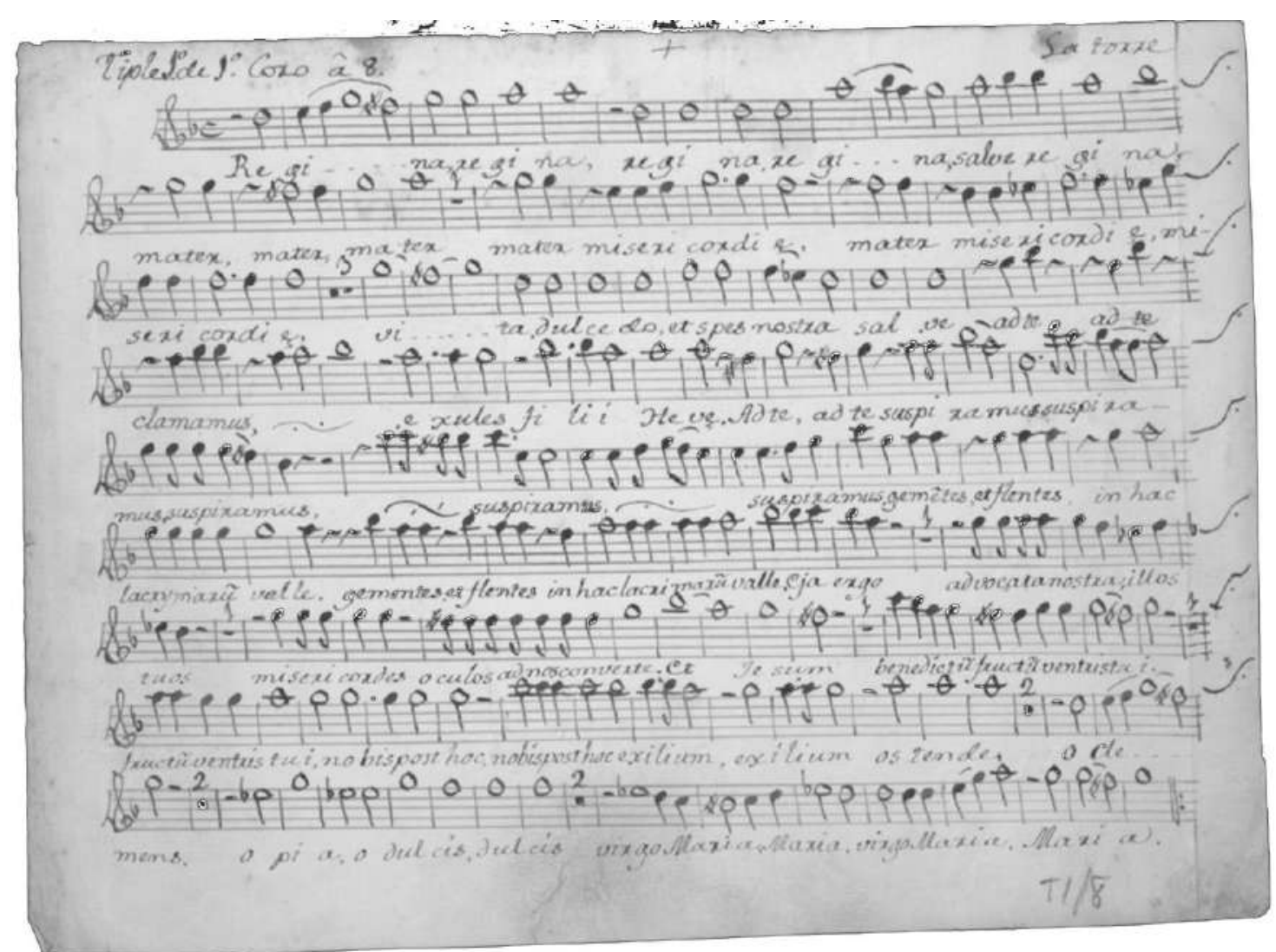

Fig. 17: Salve Regina: "parte de tiple $1^{\circ}$ del $1^{\circ}$ coro".

To compare the performance and suitability of the proposal, we have first encoded part of the content directly into MEI using Oxygen ${ }^{12}$, taking us between around 12 minutes per staff, being difficult to concentrate on the direct transcription process from the manuscript while writing XML code. When we have moved to the second and the rest of voices, the problem has been even worse due to the MEI staff separation architecture. In contrast, the encoding using **mens has taken us between 2 and 3 minutes for each staff, including the time to make those interpretation decisions of the original manuscript. Perhaps the most interesting feature is the ability of ${ }^{* *}$ kern, inherited by $* *$ mens, to represent in a very efficient way the simultaneity of voices, which has helped us in particular to deduce the correct transcription in situations of ambiguity so common in this kind of manuscripts, due in many cases to ink blots, paper holes and dropped ink, where sometimes we do not know which symbol the copyist wanted to represent (see Fig. 18).

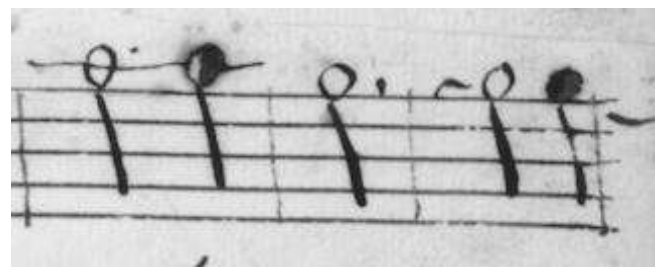

Fig. 18: Some possible amiguities.

${ }^{12}$ https://www.oxygenxml.com 


\section{White MENSURAL MANUAL ENCODING: FROM HUMdRUM TO MEI}

From the work encoding in ${ }^{* *}$ mens (see Fig. 21 ), several outputs have been generated using our own library IM3:

- the score engraved using an extension of the Capitán calligraphic typography (Pascual Hernández, 2014) named Patriarca containing the original content aligned to an automatically generated modern transcription below each staff (see Fig. 19).

- the MEI encoding (see Fig. 20) and a Verovio printed version (Pugin et al., 2014) (see Fig. 22).

- a Lilypond rendering using the mensural context (see Fig. 23).

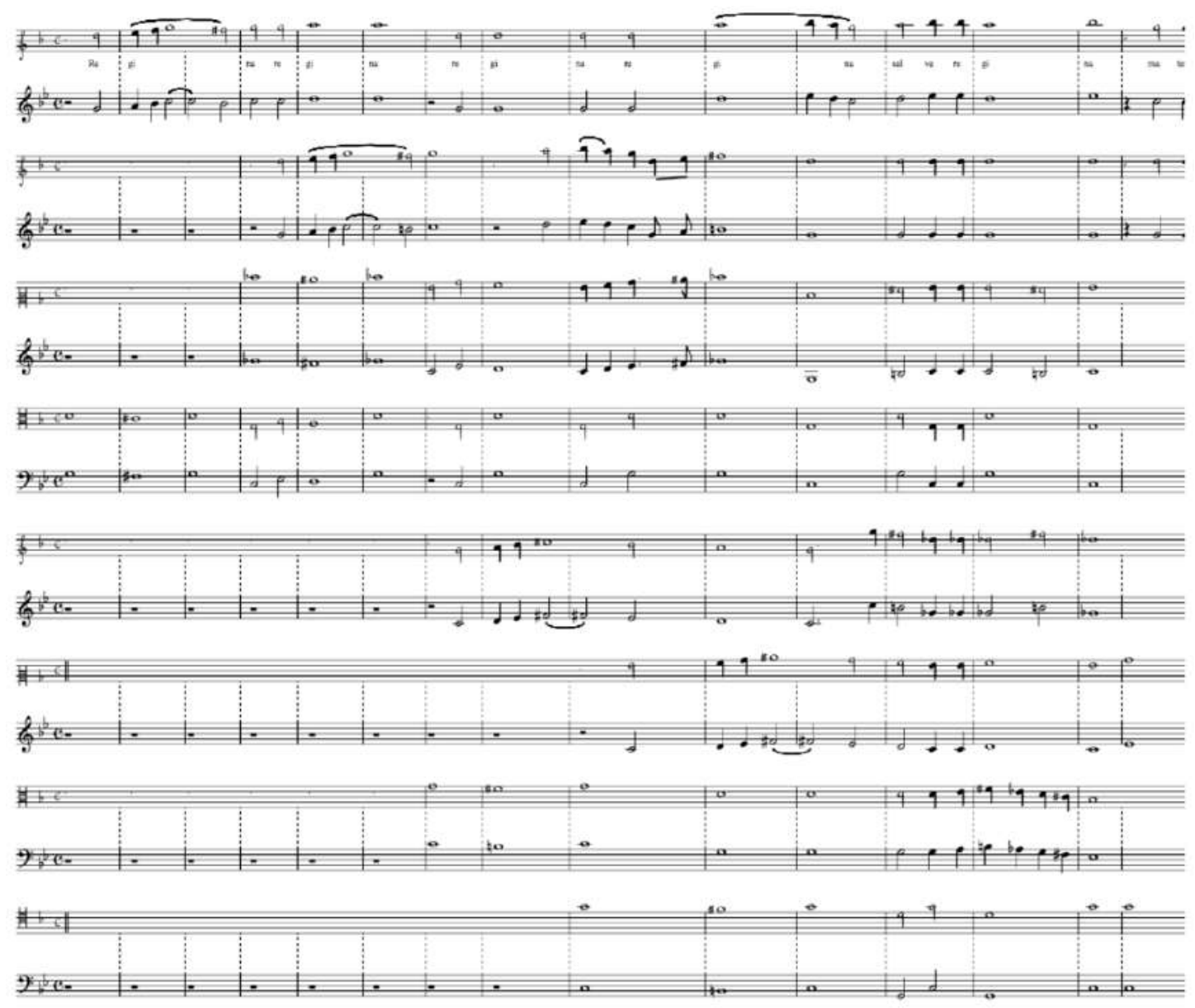

Fig. 19: IM3 engraving of mensural and modern transcription (excerpt). 


\section{David Rizo Valero, Nieves Pascual León y Craig Stuart SapP}

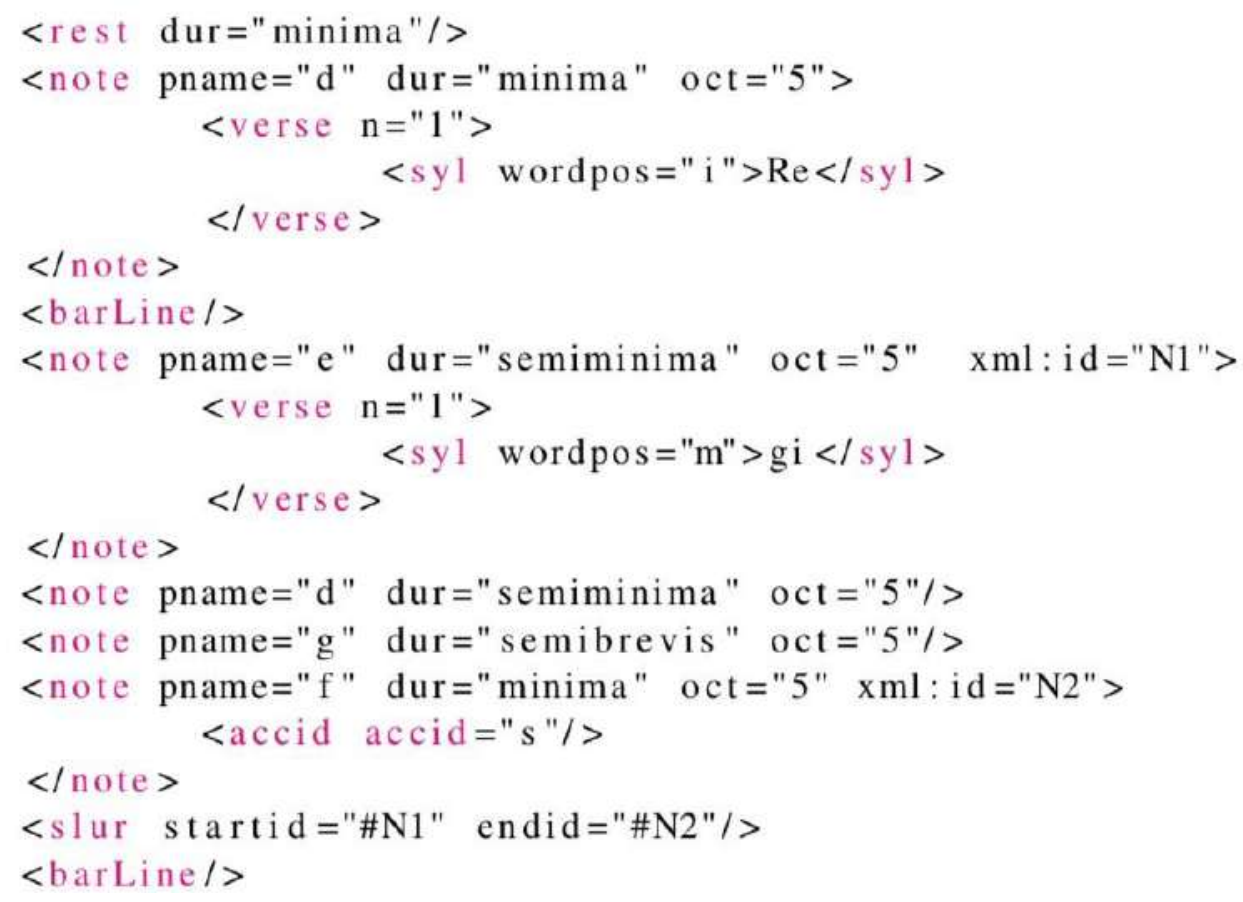

Fig. 20: Extract of MEI encoding of manuscript.

\begin{tabular}{|c|c|c|c|c|c|c|c|}
\hline *mens & $\star *$ mens & $\star \star$ mens & $\star \star$ mens & $* \star$ mens & $\star \star$ mens & $\star \star$ mens & $\star \star$ mens \\
\hline staff 8 & *staff 7 & *staff 6 & *staff 5 & *st a ff 4 & *staf $f 3$ & *staff2 & *staff 1 \\
\hline clefC 4 & *clefC 3 & $\star c l e f C 2$ & *clefG2 & $\star c l e f C 3$ & *clefc 2 & *clefG2 & *clefG 2 \\
\hline$k[b-]$ & $\star k[b-]$ & $\star k[b-]$ & $\star k[b-]$ & $\star k[b-]$ & $\star k[b-]$ & $\star k[b-]$ & $\star k[b-]$ \\
\hline M4 / 4 & $\star \mathrm{M} 4 / 4$ & $\star \mathrm{M} 4 / 4$ & $\star \mathrm{M} 4 / 4$ & $\star M 4 / 4$ & $\star \mathrm{M} 4 / 4$ & $\star \mathrm{M} 4 / 4$ & $\star \mathrm{M} 4 / 4$ \\
\hline met (C) & $\star \operatorname{met}(\mathrm{C})$ & $\star \operatorname{met}(\mathrm{C})$ & $\star \operatorname{met}(\mathrm{C})$ & $\star \operatorname{met}(\mathrm{C})$ & $\star \operatorname{met}(\mathrm{C})$ & $\star \operatorname{met}(\mathrm{C})$ & $\star \operatorname{met}(\mathrm{C})$ \\
\hline $\mathrm{Xr}$ & sr & $\mathrm{Xr}$ & sr & sd & sr & sr & Mr \\
\hline . & . & . & . & . & . & . & Mdd \\
\hline$!$ & $!$ & $!$ & $!$ & $=$ & $!$ & ! & $=$ \\
\hline . & sr & . & sr & sc\# & sr & sr & mee \\
\hline . & . & . & . & . & . & . & $\operatorname{mff}$ \\
\hline . & . & . & . & . & . & . & sgg \\
\hline ! & ! & ! & $!$ & $=$ & $!$ & ! & $!$ \\
\hline . & sr & . & sr & $\mathrm{sd}$ & sr & sr & . \\
\hline . & . & . & . & . & . & . & Mff\# \\
\hline ! & $!$ & $!$ & $!$ & $=$ & $=$ & $=$ & $=$ \\
\hline${ }^{\circ}$ & sr & . & sr & MG & sdd- & Mr & Mgg \\
\hline 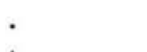 & . & . & . & MB- & . & Mdd & Mgg \\
\hline$!$ & $!$ & $!$ & $!$ & $=$ & $=$ & $=$ & $=$ \\
\hline . & sr & . & sr & $s A$ & scc\# & mee & saa \\
\hline · & . & . & . & . & . & $\operatorname{mff}$ & . \\
\hline
\end{tabular}

Fig. 21: Extract of Humdrum encoding using **mens. 
WHite MENSURAL MANUAL ENCODING: FROM HUMdRUM TO MEI

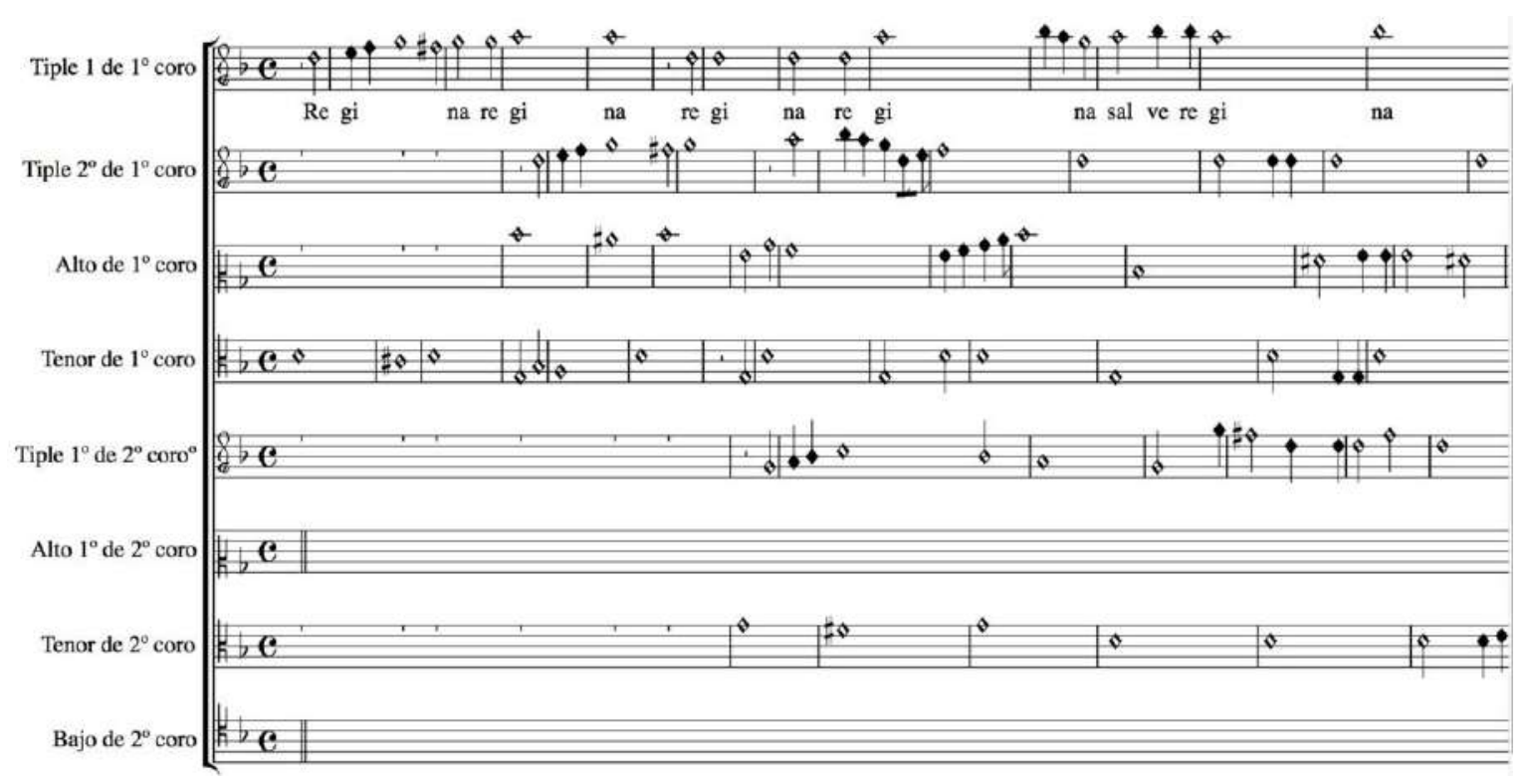

Fig. 22: Verovio engraving (excerpt).

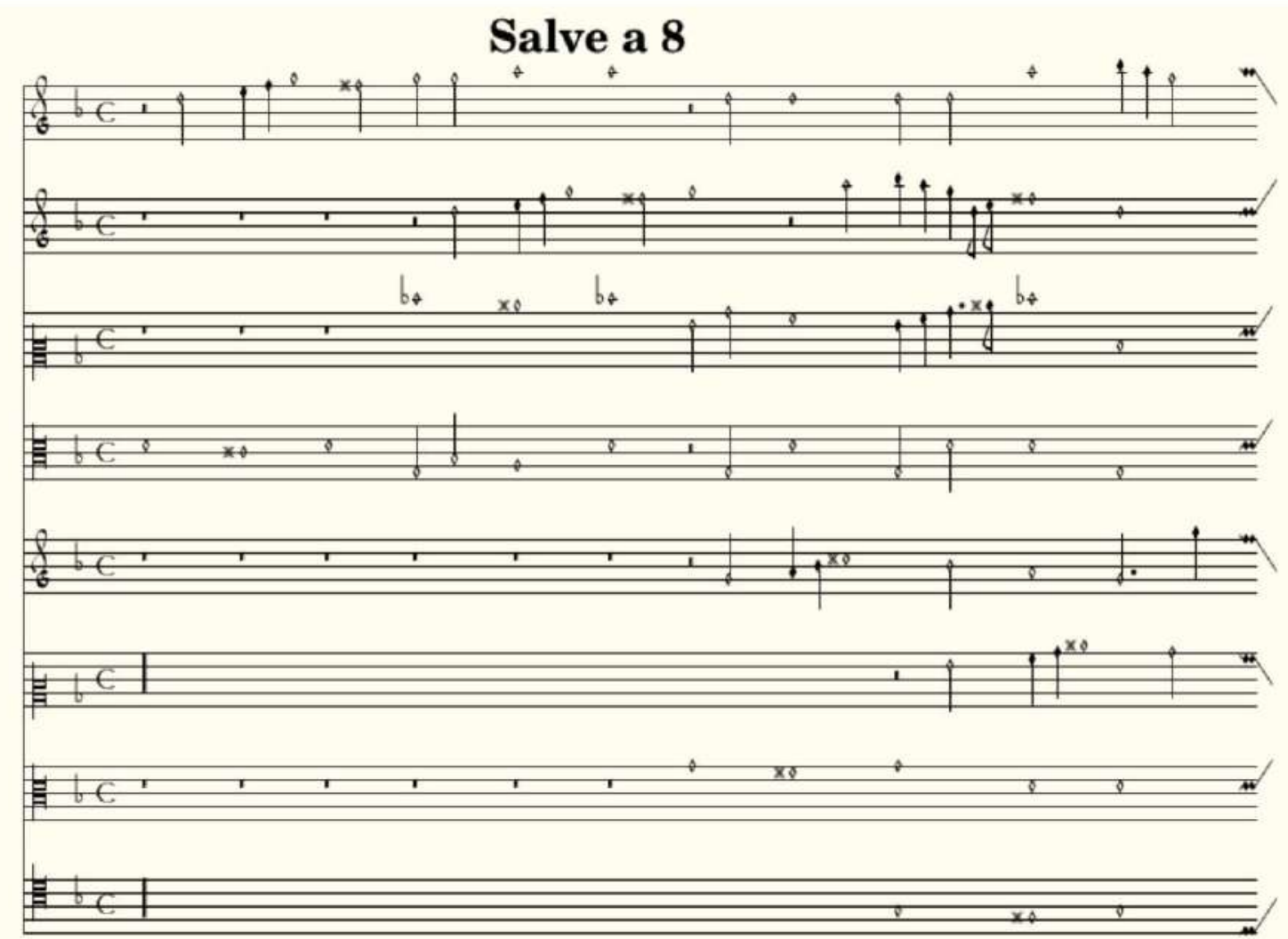

Fig. 23: Lilypond engraving (excerpt). 


\section{David Rizo Valero, Nieves Pascual León y Craig Stuart Sapp}

\section{CONCLUSIONS}

In this article an efficient alternative to encode transcriptions directly in MEI format has been introduced that uses an extension of *kern syntax named **mens, and solutions for issues specific to white mensural notation have been detailed. From the **mens input, some examples of different outputs has been presented that show the suitability of the approach. Given the fact ${ }^{* *}$ mens has been processed both by Verovio Humdrum Viewer and IM3 library, we demonstrate the proposed encoding is complete and well-formed, not depending on any specific framework as happens with Lilypond.

The work is still in progress, so many options are to be still implemented in the near future.

\section{BIBLIOGRAPHY}

De Jaime Gómez, J. and De Jaime Lorén, J. M. (1988). "Jerónimo de la Torre (Calamocha 1607-1673): compositor y organista”. Xiloca. Revista del Centro de Estudios del Jiloca, $\mathrm{n}^{\circ}$ 2, pp. $71-85$.

Dumitrescu, T. and Berchum, M. v. (2009). "The CMME Occo Codex Edition: Variants and Versions in Encoding and Interface", in Stadler, P. and Veit, J. (eds.): Digitale Edition zwischen Experiment und Standarisierung. Berlin and New York: Walter de Gruyter.

Good, M. and Actor, G. (2003). "Using MusicXML for File Interchange". International Conference on Web Delivering of Music, International Conference.

Huron, D. (2002). "Music Information Processing Using the Humdrum Toolkit: Concepts, Examples, and Lessons". Computer Music Journal, n 26-2, pp. 11-26.

Kirkman, A. (2015). "Review: The Josquin Research Project by Jesse Rodin and Craig Sapp". Journal of the American Musicological Society, no 68-2, pp. 455-465.

MIDI (1996). The Complete MIDI 1.0 Detailed Specification: : Incorporating All Recommended Practices. MIDI Manufacturers Association, MMA.

Parada-Cabaleiro, E., Batliner, A., Baird, A., and Schuller, B. W. (2017). "The SEILS dataset: simbollically: symbolically encoded scores in modern-early notation for computational musicology". International Society for Music Information Retrieval Conference, Suzhou, China. 


\section{White MENSURAL MANUAL ENCODING: FROM HUMdRUM TO MEI}

Parr, T. The Definitive ANTLR 4 Reference. The Pragmatic Programmers, LLC.

Pascual Hernández, B. (2014). Tipografía musical "Solera". Final Year Project. Alicante: Escola d'Art i Superior de Disseny d'Alacant.

Pugin, L. (2009). "Editing Renaissance Music: The Aruspix Project". Digitale Edition zwischen Experiment und Standardisierung: Musik -- Text -- Codierung, nº. 36, pp. 94-103.

Pugin, L., Zitellini, R., and Roland, P. (2014). "Verovio - A library for Engraving MEI Music Notation into SVG”. International Society for Music Information Retrieval.

Querol Gavaldá, M. (1975). Transcripción e interpretación de la polifonía española de los siglos XV y XVI. Madrid: Comisaría Nacional de la Música.

Rigaux, P., Abrouk, L., Audéon, H., Cullot, N., Rigaux, C. D., Faget, Z., Gavignet, E., Amblard, D. G., Tacaille, A., and Goasdoué, V. T. (2012). "The design and implementation of Neuma, a collaborative Digital Scores Library - Requirements, architecture, and models". International Journal on Digital Libraries, n ${ }^{\circ} 12-2 / 3$, pp. 7388.

Wyn Jones, D. (2003). “Sinfonías austriacas en el Palacio Real de Madrid”, en M. Boyd y J. J. Carreras (eds.), La música en España en el siglo XVIII, pp. 145-166. Madrid: Cambridge University Press.

Fecha de recepción: 18/07/2018

Fecha de aceptación: 10/09/2018 